\title{
Effect of intermittent watering on dry matter intake and body weight of male Ethiopian Somali goats*
}

\author{
U. Mengistu ${ }^{1}$, K. Dahlborn ${ }^{2}$ and K. Olsson ${ }^{2}$ \\ ${ }^{1}$ Department of Animal Sciences, Alemaya University (AU) \\ P.O. Box138, Dire-Dawa, Ethiopia \\ ${ }^{2}$ Departmen of Anatomy and Physiology, Swedish University of Agricultural Sciences (SLU) \\ SE-750 07, Uppsala, Sweden
}

\begin{abstract}
Twenty-six male Ethiopian Somali goats were used. Access to water every 48, 72 or $96 \mathrm{~h}$ reduced $(\mathrm{P}<0.001)$ the mean water intake $\left(\mathrm{ml} / \mathrm{kg} \mathrm{W}\right.$ and $\left.\mathrm{ml} / \mathrm{kg} \mathrm{W}^{0.75}\right)$ and the water to feed ratio (ml/g DMI) compared to every $24 \mathrm{~h}$ with no difference between the 48 and $72 \mathrm{~h}$. Dry matter intakes $\left(\mathrm{g} / \mathrm{kg} \mathrm{W}\right.$ and $\left.\mathrm{g} / \mathrm{kg} \mathrm{W}^{0.75}\right)$ were reduced only at $96 \mathrm{~h}(\mathrm{P}<0.01)$. Final body weight and daily gain were not affected by the watering regimes. We conclude that this goat breed tolerate prolonged periods of dehydration and can be watered once every three days.
\end{abstract}

\section{INTRODUCTION}

In the arid and semi-arid regions, water is limited both in total amount and availability. The scarcity is persistent and severe particularly in the dry season, during which livestock cannot have access to water on a free choice basis. At this time of the year, pastorlists economize on water through intermittent watering. However, the practice can impose dehydration and physiological stress, which requires its wise implementation. Some authors (Abdelatif and Ahmed, 1994; Silanikove, 1994; Adogla-Bessa and Aganga, 2000) have reported the ability of desert-adapted ruminants to tolerate prolonged periods of water deprivation. Although goats are abundant in the arid and semi-arid regions of Ethiopia, information available on the effects of intermittent watering on animal welfare and productivity is limited. Therefore, there is a need for understanding the ability as well as the mechanism of withstanding water shortage by the indigenous goat breeds. This study was designed

\footnotetext{
* Supported by SIDA/SAREC-AU-SLU, PhD. Programme

${ }^{1}$ Corresponding author: e-mail: urgeletta@yahoo.com
} 
to investigate the effect of intermittent watering regimes on water and dry matter intake and body weight changes of Ethiopian Somali goats.

\section{MATERIAL AND METHODS}

The study was conducted at the Errer Valley camel research center, Eastern Ethiopia. Twenty-eight (seven goats per treatment) intact male Ethiopian Somali goats of about 8 to 10 months of age with the average body weight of $18.0 \pm 1.2 \mathrm{~kg}$ were randomly distributed to treatment groups according to body weight. The experiment period consisted of 72 days, which was divided into 6 periods of 12 days each. During the first four days of each period, each goat was put into a metabolic cage $(1.2 \times 0.8$ $\mathrm{cm}$ ) placed in a well-ventilated corrugated sheet house. At the end of the fourth day of a particular period, the goats were moved into outdoor individual pens $(2 \times 1.5 \mathrm{~m})$. The pens were covered with sparse grass over the roof to protect the goats from direct sun. Water was offered individually once every $24 \mathrm{~h}$ (W1), once every $48 \mathrm{~h}$ (W2), once every $72 \mathrm{~h}$ (W3), or once every $96 \mathrm{~h}$ (W4) for a period of 90 min following feed distribution. Goats were fed grass hay $(\mathrm{ME}=9.8 \mathrm{MJ} / \mathrm{kg} \mathrm{DM}$ and $\mathrm{CP}=59 \mathrm{~g} / \mathrm{kg}$ $\mathrm{DM})$ as a basal diet ad libitum and were supplemented with $200 \mathrm{~g}$ of concentrates (mixture of wheat bran and peanut cake, $\mathrm{ME}=12.49 \mathrm{MJ} / \mathrm{kg} \mathrm{DM}$ and $\mathrm{CP}=340 \mathrm{~g} / \mathrm{kg}$ DM) individually. Hay and concentrates were weighed and offered between 12.00 to $13.00 \mathrm{~h}$ every day. Refusals of both hay and concentrates were collected the next day and weighed before offering fresh feed. Body weight was measured every day when the goats were indoors and once every fourth day when they were outdoors between 7.00 and $8.00 \mathrm{~h}$. Data were analysed using the SAS software (SAS Institute, 1996). The repeated measurement analysis of variance (procedure MIXED) was applied to the respective parameters. Data from two goats, one each from W2 and W4, were removed because of high parasite loads and poor performances.

Table 1. Effect of intermittent watering on water and dry matter intake (DMI) of Ethiopian Somali goats (Lsmeans $\pm \mathrm{SE}$ )

\begin{tabular}{|c|c|c|c|c|}
\hline \multirow{2}{*}{ Parameters } & \multicolumn{4}{|c|}{ Watering treatments } \\
\hline & W1 & $\mathrm{W} 2$ & W3 & W4 \\
\hline \multicolumn{5}{|l|}{ Water intake } \\
\hline average intake, $\mathrm{ml} /$ day & $1287 \pm 41^{\mathrm{a}}$ & $870 \pm 48^{\mathrm{bc}}$ & $890 \pm 48^{b}$ & $736 \pm 55^{\mathrm{c}}$ \\
\hline water:feed, ml/g DMI & $2.23 \pm 0.06^{\mathrm{a}}$ & $1.62 \pm 0.06^{\mathrm{b}}$ & $1.56 \pm 0.06^{\mathrm{b}}$ & $1.35 \pm 0.06^{\mathrm{c}}$ \\
\hline $\mathrm{ml} / \mathrm{kg}$ body weight & $63.88 \pm 1.6^{\mathrm{a}}$ & $43.40 \pm 1.7^{b}$ & $41.72 \pm 1.6^{\mathrm{b}}$ & $35.06 \pm 1.7^{\mathrm{c}}$ \\
\hline $\mathrm{ml} / \mathrm{kg} \mathrm{W}^{0.75}$ & $135.23 \pm 3.2^{\mathrm{a}}$ & $91.79 \pm 3.5^{\mathrm{b}}$ & $89.33 \pm 3.2^{\mathrm{b}}$ & $74.99 \pm 3.5^{\mathrm{c}}$ \\
\hline \multicolumn{5}{|l|}{ Dry matter intake } \\
\hline average intake, g/day & $578 \pm 9.9^{\mathrm{a}}$ & $537 \pm 10.6^{\mathrm{b}}$ & $562 \pm 10.9^{\mathrm{ab}}$ & $535 \pm 10.7^{b}$ \\
\hline $\mathrm{g} / \mathrm{kg} \mathrm{W}$ & $28.6 \pm 0.7^{\mathrm{a}}$ & $26.9 \pm 0.8^{\mathrm{ab}}$ & $26.8 \pm 0.7^{\mathrm{ab}}$ & $26.1 \pm 0.8^{\mathrm{b}}$ \\
\hline $\mathrm{g} / \mathrm{kg} \mathrm{W}^{0.75}$ & $60.6 \pm 1.3^{\mathrm{a}}$ & $56.8 \pm 1.4^{\mathrm{ab}}$ & $57.3 \pm 1.3^{\mathrm{ab}}$ & $55.9 \pm 1.4^{\mathrm{b}}$ \\
\hline
\end{tabular}

values within the same row with different letters differ 


\section{RESULTS}

The mean daily water intake of the group watered once every $24 \mathrm{~h}$ was higher than the calculated means of other groups both in absolute $(\mathrm{ml} /$ day) and relative terms $\left(\mathrm{ml} / \mathrm{g} \mathrm{DMI}, \mathrm{ml} / \mathrm{kg}\right.$ body weight or $\left.\mathrm{ml} / \mathrm{kg} \mathrm{W}^{0.75}\right)(\mathrm{P}<0.001)$. W2 and $\mathrm{W} 3$ consumed the same amounts of water, which were higher than W4 (Table 1).

$\mathrm{W} 1$ consumed larger amounts of dry matter (g/day) compared to W2 and $\mathrm{W} 4(\mathrm{P}<0.01)$, but the same amounts as W3 (Table 1). There were no differences between the latter three groups. When dry matter intake was expressed in relative terms $\left(\mathrm{g} / \mathrm{kg}\right.$ body weight or $\left.\mathrm{g} / \mathrm{kg} \mathrm{W} \mathrm{W}^{0.75}\right)$, W1 consumed larger amounts compared with W4 $(\mathrm{P}<0.05)$ and similar amounts as $\mathrm{W} 2$ and $\mathrm{W} 3$. The latter three groups consumed the same amounts of dry matter in relative terms. Final body weight and average daily gain were not significantly different between the treatment groups (Table 2).

Table 2. Effect of intermittent watering on daily weight gain of Ethiopian Somali goats (Lsmeans \pm SE)

\begin{tabular}{lcccc}
\hline \multirow{2}{*}{ Parameters } & \multicolumn{4}{c}{ Watering treatments } \\
\cline { 2 - 5 } & $\mathrm{W} 1$ & $\mathrm{~W} 2$ & $\mathrm{~W} 3$ & $\mathrm{~W} 4$ \\
\hline Initial body weight, $\mathrm{kg}$ & $17.7 \pm 0.5$ & $18.0 \pm 0.5$ & $17.8 \pm 0.5$ & $18.5 \pm 0.5$ \\
Final body weight, $\mathrm{kg}$ & $20.2 \pm 0.7$ & $20.1 \pm 0.8$ & $21.1 \pm 0.7$ & $21.1 \pm 0.8$ \\
Total gain, kg & $2.5 \pm 0.5$ & $2.1 \pm 0.5$ & $3.3 \pm 0.5$ & $2.6 \pm 0.5$ \\
Daily gain, g/day & $35 \pm 7$ & $29 \pm 7$ & $46 \pm 7$ & $36 \pm 7$ \\
\hline
\end{tabular}

\section{DISCUSSION}

The current finding of decreased calculated average daily water intake with prolonged periods of water deprivation is in agreement with Abdelatif and Ahmed (1994) who reported a reduced water intake of rams watered at an interval of 24, 48 and $72 \mathrm{~h}$ compared to rams that had a free access to water. Adogla-Bessa and Aganga (2000) also reported a lower free water intake of Tswana goats, which were water deprived for 48 and $72 \mathrm{~h}$ compared to those watered every $24 \mathrm{~h}$. The authors also observed a decrease in the amount of water drunk per $\mathrm{kg}$ metabolic body weight with increasing watering intervals. The lower average water consumption in groups $\mathrm{W} 2, \mathrm{~W} 3$ and $\mathrm{W} 4$ compared to $\mathrm{W} 1$ indicates that these goats economize on the water during periods of water scarcity.

Similar to the current finding, Adogla-Bessa and Aganga (2000) reported a decrease in the ratio of water to feed intake with increasing watering interval, which they attributed to the increase in the space available for feed in the reticulorumen because of the reduced water consumption. However, there was no increase in the total amount of dry matter intake by the groups subjected to water deprivation both in the reports of Adogla-Bessa and Aganga (2000) and in our 
experiment. Therefore, it seems that it is not the increase in dry matter intake, but the decrease in the mean water intake with increasing watering interval, which is the cause of the decreased ratio of water to feed intake.

Dry matter intake per $\mathrm{kg}$ metabolic body weight $\left(\mathrm{g} / \mathrm{kgW}^{0.75}\right)$ decreased with prolonged watering intervals. That finding is not in agreement with that of Adogla-Bessa and Aganga (2000) who reported increased dry matter intake per kg metabolic weight from the ad libitum to $72 \mathrm{~h}$ watering intervals in Tswana goats. The difference between the two findings could be a result of the decrease in body weight of the Tswana goats unlike the Ethiopian Somali goats, which showed a similar weight gain in all groups.

Zewdu (1991) reported the same final body weight and daily gain of Black Head Ogaden sheep watered at intervals of once every 24,48 and $72 \mathrm{~h}$ with those for which water was available freely. These findings are in agreement with our results in the male Ethiopian Somali goats. The animals' ability to endure water shortage could be due to the fact that they are owned by pastoralists and are familiar to the long watering intervals under even more stressful environment and feed shortage.

\section{CONCLUSIONS}

It is concluded that this goat breed is well adapted to the desert environment and that young male goats can be watered once every $72 \mathrm{~h}$ during periods of water shortage and yet attain a reasonable body weight gain.

\section{REFERENCES}

Abdelatif A.M., Ahmed M.M.M., 1994. Water restriction, thermoregulation, blood constituents and endocrine responses in Sudanese desert sheep. J. Arid Environ. 26, 171-180

Adogla-Bessa T., Aganga A.A., 2000. Responses of Tswana goats to various lengths of water deprivation. S. Afr. J. Anim. Sci. 30, 87-91

Aganga A. A., 1992. Water utilization by sheep and goats in Northern Nigeria. World Anim. Rev., FAO $73,9-14$

SAS Institue, 1996. SAS User's Guide Statistics, Version 6.12. SAS Institute Inc., Cary, NC

Silanikove N., 1994. The struggle to maintain hydration and osmoregulation in animals experiencing severe dehydration and rapid re-hydration: the story of ruminants. Exp. Physiol. 79, 281-300

Zewdu S., 1991. Effect of watering frequency on water budget, feed intake, nutrient utilization, body weight change and subsequent survival of black head Ogaden sheep. MSc. Thesis, Alemaya University of Agriculture, Alemaya (Ethiopia) 